\title{
Peran Pemerintah dalam Pengembangan Kawasan Ekonomi Khusus Mandalika Provinsi Nusa Tenggara Barat
}

\author{
Zulfan Asri Ramdani, M. Sani Roychansyah, Yori Herwangi \\ Departemen Teknik Arsitektur dan Perencanaan, Magister Perencanaan Wilayah dan Kota, Universitas Gadjah Mada \\ zu_ra@rocketmail.com
}

\begin{tabular}{l} 
INFO ARTIKEL \\
\hline Riwayat Artikel: \\
Diterima: $20-02-2020$ \\
Disetujui: 30-04-2020
\end{tabular}

\section{Kata Kunci:}

Institutional Setting

Pariwisata

Kawasan Ekonomi

Khusus

\begin{abstract}
ABSTRAK
Abstrak: Pariwisata saat ini menjelma menjadi suatu industri yang secara aktif dipromosikan menjadi mesin penggerak ekonomi. Kawasan ekonomi khusus (KEK) merupakan salah satu pengembangan pariwisata yang dilakukan pemerintah untuk menggerakkan ekonomi masyarakat Salah satu kawasan ekonomi khusus yang berkaitan dengan pengembangan pariwisata adalah kawasan ekonomi khusus Mandalika yang berlokasi di kabupaten Lombok Tengah, Nusa Tenggara Barat. Penelitian ini bertujuan untuk mengkaji mengenai institutional setting pengembangan Kawasan Ekonomi Khusus Mandalika untuk melihat cakupannya dan dampaknya untuk kawasan tersebut. Kategori yang akan dibahas pada penelitian ini adalah spasial dan pariwisata. Pendekatan yang dilakukan dalam penelitian ini adalah pendekatan kualitatif dengan teknik pengumpulan data dilakukan melalui wawancara dan observasi. Hasil penelitian menunjukkan bahwa pemerintah kabupaten Lombok Tengah sebagai aktor pengembangan Kawasan Ekonomi Khusus Mandalika yang berperan paling besar dibandingkan level pemerintah yang lainnya. Hal ini bisa terlihat pada institutional setting aspek spasial. Rencana Induk Pengembangan Pariwisata Daerah Kabupaten Lombok Tengah memberikan penjelasan secara detail mengenai pembagian kawasan pariwisata menjadi kawasan pengembangan utara, kawasan pengembangan tengah, dan kawasan pengembangan selatan. Sedangkan peraturan lain yang menyangkut Kawasan Ekonomi Khusus Mandalika hanya membahas mengenai delineasi dan batas-batasnya saja.
\end{abstract}

\begin{abstract}
Tourism is currently transformed into an industry that is actively promoted to be an economic engine. Special economic zones (KEK) is one of the tourism development carried out by the government to drive the community's economy. One of the special economic zones related to tourism development is the Mandalika special economic zone located in Central Lombok regency, West Nusa Tenggara. This study aims to examine the institutional setting for developing the Mandalika Special Economic Zone to see its scope and impact on the region. The categories that will be discussed in this study are spatial and tourism. The approach taken in this research is a qualitative approach with data collection techniques carried out through interviews and observations. The results showed that the Central Lombok district government as an actor in the development of the Mandalika Special Economic Zone played the most role compared to other levels of government. This can be seen in the institutional setting of spatial aspects. Central Lombok Regional Tourism Development Master Plan provides a detailed explanation of the division of tourism areas into northern development areas, central development areas, and southern development areas. While other regulations concerning the Mandalika Special Economic Zone only discuss delineation and its boundaries.
\end{abstract}

\section{A. LATAR BELAKANG}

Pariwisata saat ini menjelma menjadi suatu industri yang secara aktif dipromosikan menjadi salah satu mesin penggerak ekonomi. Hal ini menyebabkan pariwisata menjadi salah satu sumber pendapatan daerah (Hakim, 2004). Pengembangan pariwisata sangat diperlukan karena pariwisata memiliki multiplier effect yang menjangkau hampir seluruh lapisan masyarakat (Kotler et al., 1993).

Perekonomian masyarakat yang bersumber dari pariwisata bisa berupa kegiatan-kegiatan di destinasi pariwisata yang dikunjungi pengunjung (Çakmak et al.,
2018). Semakin kompetitif destinasi pariwisata maka semakin banyak pula wisatawan yang akan mendatangi destinasi pariwisata tersebut (Manrai et al., 2018). Implikasinya kegiatan-kegiatan yang ada di destinasi pariwsata tersebut akan berkembang dan menghasilkan nilai ekonomi bagi pelaku-pelaku yang berkegiatan di destinasi pariwisata tersebut (Law et al., 2017).

Pengembangan pariwisata saat ini semakin berkembang dang bervariasi dari waktu ke waktu. Pemerintah mengeluarkan kebijakan pengembangan ekonomi yang juga berkaitan dengan pengembangan pariwisata, yakni Kawasan Ekonomi Khusus. Salah satu 
Kawasan Ekonomi Khusus yang berkaitan dengan pengembangan pariwisata adalah Kawasan Ekonomi Khusus Mandalika.

Kawasan Ekonomi Khusus Mandalika berlokasi di kabupaten Lombok Tengah, Nusa Tenggara Barat. Kawasan Ekonomi Khusus Mandalika memiliki luas wilayah kurang lebih 1.250 ha. Kawasan ini berjarak 16 $\mathrm{km}$ dari Bandara Internasional Lombok, $55 \mathrm{~km}$ dari pelabuhan Lembar, dan $45 \mathrm{~km}$ dari kota Mataram yang merupakan ibukota provinsi Nusa Tenggara Barat.

Konsep bisnis yang dikembangkan di Kawasan Ekonomi Khusus Mandalika dibagi menjadi dua, yakni public realm dan private realm. Public realm merupakan konsep bisnis yang mengembangkan fasilitas-fasilitas yang menunjang keberlangsungan kawasan tersebut seperti infrastruktur transportasi, jaringan utilitas yang mencakup listrik, air, dan gas, jaringan komunikasi, taman, sarana olahraga dan hiburan, pelayanan public seperti perdagangan, kesehatan, dan keamanan, serta agro-tourism dan sarana peribadatan. Sedangkan Private realm merupakan konsep bisnis yang mengembangkan Independent Development Packages seperti hotel, spa, tempat konferensi, dan museum serta tempat kerajinan.

Pemerintah kabupaten memiliki peran untuk ikut mengembangkan Kawasan Ekonomi Khusus Mandalika melalui institutional setting. Pemerintah kabupaten dalam hal ini Lombok Tengah dirasa mempunyai kuasa untuk ikut menguatkan dan mempromosikan atraksiatraksi pariwisata yang ada di Kawasan Ekonomi Khusus Mandalika.

Dalam institutional setting, pemerintah memiliki peran untuk menguatkan dan mempromosikan pelayanan tertentu kepada masyarakat. Kawasan Ekonomi Khusus Mandalika sendiri merupakan pariwisata yang berkaitan langsung dengan masyarakat melalui multiplier effect yang dimiliki pariwisata itu sendiri. Namun institutional setting tersebut harus menjangkau semua multiplier effect dari pariwisata yang ada sehingga akan mampu mencakup dan mengoptimalkan potensi-potensi yang ada di kawasan tersebut. Oleh sebab itu perlu dikaji mengenai institutional setting pengembangan Kawasan Ekonomi Khusus Mandalika untuk melihat cakupannya dan dampaknya untuk kawasan tersebut.

\section{B. METODE PENELITIAN}

Pendekatan yang dilakukan dalam penelitian ini adalah pendekatan kualitatif. Pendekatan kualitatif merupakan pendekatan yang melakukan eksplorasi terhadap sebuah tempat (Taguchi, 2018). Fokus utama dari pendekatan kualitatif adalah memperoleh pemahaman terhadap suatu kejadian atau fenomena melalui wawancara dan observasi (Distanont et al., 2018).

Penelitian kualitatif ini membahas institutional setting yang ada di Kawasan Ekonomi Khusus Mandalika. Kawasan Ekonomi Khusus Mandalika merupakan arahan dari pemerintah pusat yang memiliki skala nasional, sehingga perlu dilihat bagaimana masing-masing skala pemerintahan yang ada di dalamnya dari yang skalanya tertinggi di pemerintah pusat hingga yang skalanya terendah di pemerintah desa atau kelurahan dalam mengintegrasikan peraturan baku yang disusun untuk mengembangkan Kawasan Ekonomi Khusus Mandalika.

Penelitian ini dilakukan di Kawasan Ekonomi Khusus Mandalika. Kawasan Ekonomi Khusus Mandalika memiliki luas 1.035,67 ha (seribu tiga puluh lima koma enam puluh tujuh hektar) yang terletak dalam wilayah Kecamatan Pujut, Kabupaten Lombok Tengah, Provinsi Nusa Tenggara Barat.

Sasaran penelitian pemetaan institusi yang berwenang dan identifikasi kebijakan masing-masing institusi dilakukan dengan teknik pengumpulan data berupa wawancara dan observasi.

Wawancara adalah kegiatan pengumpulan data yang dilakukan peneliti dengan cara menanyakan secara langsung pada sumber informasi (Yunus, 2010). Sumber informasi pada penelitian ini adalah dinas-dinas yang terkait dengan Kawasan Ekonomi Khusus Mandalika dari berbagai skala pemerintahan. Pemetaan institusi yang berwenang di Kawasan Ekonomi Khusus Mandalika dilakukan dengan wawancara mulai dari skala terendah di pemerintah desa/ kelurahan hingga skala tertinggi yang memungkinkan di pemerintah pusat.

Observasi adalah kegiatan mengamati kejadian atau lokasi tertentu yang memiliki hubungan sebab akibat dengan hal-hal yang biasa terjadi (Yunus, 2010). Observasi dilakukan untuk mendapatkan data peraturan baku yang sudah dijalankan di Kawasan Ekonomi Khusus Mandalika. Implementasi dari peraturan yang ada diobservasi untuk mengidentifikasi kewenangan dan intergrasi antar peraturan yang dikeluarkan oleh masingmasing institusi dari skala tertinggi di pemerintah pusat hingga skala terendah di pemerintah desa atau kelurahan.

Teknik analisis data yang dilakukan adalah Content Analysis. Penelitian ini mengkaji institutional setting dalam Kawasan Ekonomi Khusus Mandalika untuk mengisi content analysis yang dilakukan. Institutional setting adalah peraturan baku yang berjenjang berdasarakan skala cakupan peraturan tersebut mulai dari nasional hingga tapak (Hossain et al., 2015).

Kategori yang dimasukkan dalam penelitian ini untuk menjawab tujuan penelitian adalah skala pemerintahan dari yang tertinggi di pemerintah pusat hingga yang terendah di pemerintah desa atau kelurahan. Teknik analisis ini akan memberikan pemahaman mengenai kategori-kategori yang sudah ditentukan sebelumnya (Soldatenko and Backer, 2019). Kategori yang akan dibahas pada penelitian ini adalah spasial dan pariwisata.

Kategori spasial dalam penelitian ini berkaitan dengan pengembangan Kawasan Ekonomi Khusus Mandalika berdasarkan aspek keruangan. Kategori spasial dilihat dari peraturan-peraturan yang berlaku di Kawasan Ekonomi Khusus Mandalika. Pariwisata sebagai 
kategori content analysis berkaitan dengan komponen pariwisata, yakni atraksi, amenitas, dan aksesibilitas. Komponen-komponen pariwisata yang ada pada Kawasan Ekonomi Khusus Mandalika tersebut diidentifikasi dan dianalisis menggunakan content analysis.

\section{HASIL DAN PEMBAHASAN}

\section{Spasial}

Pengelompokan content analysis berdasarkan peraturan yang ada di Kawasan Ekonomi Khusus Mandalika. Institutional setting dalam konteks spasial di Kawasan Ekonomi Khusus Mandalika dibagi menjadi 3 yakni Peraturan Pemerintah Nomor 52 Tahun 2014 tentang Kawasan Ekonomi Khusus Mandalika, Peraturan Daerah Nomor 7 Tahun 2011 tentang RTRW Kabupaten Lombok Tengah, dan Rencana Induk Pengembangan Pariwisata Daerah Kabupaten Lombok Tengah.

Institutional setting pada Peraturan Pemerintah Nomor 52 Tahun 2014 tentang Kawasan Ekonomi Khusus Mandalika lebih menekankan aspek spasial mengenai Kawasan Ekonomi Khusus Mandalika itu sendiri seperti luas keseluruhan lokasi dan juga batas-batasnya. Hal ini menjadi dasar hukum dalam pengembangan pariwisata yang ada di Kawasan Ekonomi Khusus Mandalika.

\subsection{Kewenangan}

Kewenangan yang dibahas dalam pengembangan pariwisata Kawasan Ekonomi Khusus Mandalika adalah kewenangan yang dimilki oleh masing-masing skala instansi. Skala instansi yang dibahas adalah skala nasional dan skala daerah. Kewenangan perlu dibahas untuk melihat cakupan wewenang yang dimiliki oleh masing-masing skala pemerintah. Tumpang tindih kewenangan bisa saja terjadi.

Pemerintah pusat memiliki kewenangan terhadap Kawasan Ekonomi Khusus dalam aspek spasial. Hal tersebut dijabarkan dalam Peraturan Menteri Agraria Dan Tata Ruang/ Kepala Badan Pertanahan Nasional Republik Indonesia Nomor 24 Tahun 2016 tentang Standar Pelayanan dan Pengaturan Agraria, Tata Ruang dan Pertanahan di Kawasan Ekonomi Khusus. Hak Guna Bangunan dan Hak Pakai merupakan aspek spasial yang diatur melalui pemerintah pusat. Seperti yang dijelaskan pada pasal 3:

"Jenis pelayanan sebagaimana dimaksud dalam Pasal 2 ayat (3) huruf a merupakan pelayanan yang disediakan dalam rangka pemberian, perpanjangan, dan pembaharuan Hak Guna Bangunan atau Hak Pakai, yang terdiri dari pelayanan: a. pertimbangan teknis pertanahan; b. pengukuran bidang tanah dan kawasan; c. penetapan hak atas tanah; d. pendaftaran keputusan hak atas tanah; dan e. pengelolaan pengaduan."

Pemerintah provinsi Nusa Tenggara Barat memiliki peran dalam aspek spasial melalui Peraturan Daerah Nomor 3 Tahun 2010 tentang Rencana Tata Ruang Wilayah Provinsi Nusa Tenggara Barat. Hal yang terkait dengan rencana pengembangan Provinsi Nusa Tenggara Barat dalam pengembangan Kawasan Sekitar KEK Mandalika, diantaranya:
- Penetapan sistem perkotaan, yaitu PKW Praya dan PKL Sengkol;

- Pengembangan pelabuhan perikanan nusantara (PPN) berada di Teluk Awang;

- Pengembangan bandar udara pusat pengumpul skala sekunder berada di Selaparang/Praya;

- Pengembangan terminal penumpang Kelas B di Praya;

- Pengembangan Wilayah Sungai (WS) strategis nasional adalah WS Pulau Lombok yang meliputi Daerah Aliran sungai (DAS) Dodokan, DAS Menanga, DAS Putih dan DAS Jelateng;

- Pengembangan Cekungan Air Tanah (CAT) MataramSelong seluas sekitar $2.366 \mathrm{~km} 2$;

- Pengembangan kawasan peruntukan perkebunan di Kawasan Industri Masyarakat Perkebunan (KIMBun) Pujut;

- Pengembangan kawasan peruntukan pariwisata di Dusun Sade dan sekitarnya, Selong Belanak dan sekitarnya, serta Kuta dan sekitarnya;

- Pengembangan kawasan peruntukan perikanan di Kuta, Awang dan sekitarnya; serta,

- Penetapan kawasan strategis provinsi dari kepentingan pertumbuhan ekonomi, yaitu Kute dan sekitarnya di Kabupaten Lombok Tengah, sebagian wilayah Kabupaten Lombok Barat dan sebagian wilayah Kabupaten Lombok Timur dengan sektor unggulan pariwisata, industri dan perikanan.

Pemerintah kabupaten Lombok Tengah mengatur aspek spasial seperti yang tercantum dalam Peraturan Daerah Nomor 7 Tahun 2011 tentang Rencana Tata Ruang Wilayah Kabupaten Lombok Tengah. Hal-hal yang terkait dengan rencana pengembangan Kabupaten Lombok Tengah dalam pengembangan Kawasan Sekitar KEK Mandalika, diantaranya:

- Penetapan pusat-pusat kegiatan yang meliputi Pusat Kegiatan Lokal (PKL) Sengkol, Pusat Kegiatan Lokal promosi (PKLp) Selong Belanak, Pusat Pelayanan Lingkungan (PPL) Sukadana dan Pengengat.

- Pengembangan jaringan jalan kolektor primer 2 (KP2) yang meliputi: ruas Jalan Jl. Mandalika (Praya); ruas Jalan Tanah Awu-Sengkol; ruas Jalan SengkolKuta; ruas Jalan Sp. Pengantap - Mt. Ajan - Kuta; dan ruas Jalan Kuta - Keruak.

- Pengembangan terminal penumpang tipe B yang terletak di Kota Praya, serta terminal penumpang tipe C yang terletak di Kopang, Sengkol, dan Mujur.

- Rencana pengembangan sistem jaringan transportasi laut meliputi pengembangan Pelabuhan Perikanan Nusantara (PPN) Awang di Kecamatan Pujut menjadi Pelabuhan Nasional.

- Rencana pembangunan dermaga pelabuhan penunjang pariwisata di Kecamatan Pujut dan Praya Barat.

- Pengembangan bandar udara pengumpul skala pelayanan sekunder yang meliputi Bandara Internasional Lombok (BIL) di Kecamatan Praya Barat.

- Pengembangan jaringan transmisi tenaga listrik berupa gardu induk di Kuta dan Sengkol.

- Pengembangan jaringan Saluran Udara Tegangan Tinggi (SUTT) yaitu menghubungkan Jerangjang dengan Sengkol; Sengkol dengan Selong; dan Sengkol dengan Kuta. 
- Sistem jaringan air baku untuk air minum berupa tempat penampung air di Ketare, Sengkol, Kuta, dan Rembitan.

- Pengembangan TPA dilakukan dengan sistem sanitary landfill di Desa Pengengat, Kecamatan Pujut.

\subsection{Peluang dan Tantangan}

Peluang dan tantangan yang dihadapi oleh Kawasan Ekonomi Khusus Mandalika berkaitan dengan kewenangan yang dimiliki oleh pemerintah kabupaten Lombok Tengah karena memiliki kewenangan terbanyak dengan Kawasan Ekonomi Khusus Mandalika tersebut.

\section{Pariwisata}

Tabel dibawah ini merupakan pengelompokan content analysis berdasarkan komponen pariwisata yang ada di Kawasan Ekonomi Khusus Mandalika.

\begin{tabular}{|c|c|c|}
\hline No & Komponen & Content Analysis \\
\hline 1 & Atraksi & $\begin{array}{l}\text { 1. Pantai Kuta } \\
\text { 2. Pantai Seger } \\
\text { 3. Pantai Serenting } \\
\text { 4. Bukit Merese } \\
\text { 5. Pantai Tanjung Aan } \\
\text { 6. Batu Payung } \\
\text { 7. Pantai Grupuk }\end{array}$ \\
\hline 2 & Amenitas & $\begin{aligned} & \text { - } \text { Public Realm } \\
& \circ \text { Infrastruktur } \\
& \text { Jalan, Trotoar } \\
& \circ \text { Fasilitas Transportasi: Umum } \\
& \circ \text { Pelabuhan: Cruise } \\
& \circ \text { Utilitas: Listrik, Air Minum, } \\
& \text { Gas, Air Kotor } \\
& \circ \text { Jaringan Komunikasi: Data } \\
& \circ \text { Landscape: Taman, Lampu } \\
& \circ \text { Pelayanan: Olah Raga, Hiburan } \\
& \circ \text { Fasilitas Publik: Shopping, } \\
& \text { Bank, Klinik, Ambulans, Polisi, } \\
& \text { Pemadam Kebakaran, } \\
& \circ \text { Agrowisata } \\
& \circ \text { Wisata Religi dan Budaya } \\
& \text { - Private Realm } \\
& \circ \text { Golf } \\
& \circ \text { Olah Raga Air } \\
& \circ \text { Hotel } \\
& \circ \text { Spa } \\
& \circ \text { Area Residential } \\
& \circ \text { Retail dan Restoran } \\
& \circ \text { Fasilitas Konferensi dan } \\
& \text { Eksibisi } \\
& \circ \text { Entertainment: } \\
& \text { Amusement Attractions Family } \\
& \circ \text { Museum, Balai Budaya, } \\
& \text { Kerajinan Tangan }\end{aligned}$ \\
\hline 3 & Aksesibilitas & $\begin{array}{l}\text { - Jarak menuju KEK } \\
\circ \quad 25 \text { menit dari Bali } \\
\circ \quad 1,5 \text { jam dari Jakarta } \\
\circ \quad 2 \text { jam dari Singapura } \\
\text { - } \quad \text { Lokasi } \\
\circ \quad 16 \quad \mathrm{~km} \mathrm{dari} \mathrm{Bandara} \\
\text { Internasional Lombok } \\
\circ 55 \mathrm{~km} \text { dari Pelabuhan Lembar } \\
\circ \quad 45 \mathrm{~km} \text { dari Mataram ibu kota } \\
\text { NTB }\end{array}$ \\
\hline
\end{tabular}

Kajian institutional setting dalam aspek pariwisata yang ada di Kawasan Ekonomi Khusus Mandalika diidentifikasi melalui Rencana Induk Pengembangan Pariwisata Daerah Kabupaten Lombok Tengah. Kawasan Ekonomi Khusus Mandalika sendiri berada pada kawasan pengembangan selatan dari sektor pariwisata kabupaten Lombok Tengah.

\subsection{Rencana Induk Pengembangan Pariwisata Daerah Kabupaten Lombok Tengah}

- $\quad$ Atraksi (Attractions)

Di pantai selatan Lombok Tengah terdapat kawasan pantai dan di beberapa tempat yang dipergunakan sebagai atraksi. Pada kenyataannya potensi pariwisata pantai masih banyak terdapat di kabupaten Lombok Tengah, namun belum dikembangan padahal masih banyak tempat atau lokasi pantai yang lebih menarik. Pengembangan pantai di wilayah selatan kabupaten Lombok Tengah sejauh ini dilakukan dengan strategi konservasi karena statusnya sebagai kawasan lindung. Potensi pariwisata daerah pantai selatan ini memiliki ekosistem pantai yang menarik.

Pengembangan pariwisata yang dilaksanakan kabupaten Lombok Tengah dikerjakan dengan 2 (dua) pola yaitu pola pengembangan pantai terjal (rocky beach) di bagian timur dan pantai dataran berpasir (sandy beach) di bagian barat. Keduanya mempunyai potensi daya tarik wisata alam yang sangat menarik dengan karakteristik pantai yang berbeda. Pengembangan dengan strategi big both terhadap seluruh pantai tetap dengan memperhatikan aspek saling melengkapi antar atraksi pariwisata pantai. Dengan demikian pantai akan berkembang bersama dan saling melengkapi dengan masing-masing atraksi memiliki keunggulan komparatif dan kompetitif. Pengembangan atraksi pantai lebih ditekankan pada pengembangan pariwisata bertemakan wisata minat khusus (special interest tourism) dengan melihat potensi dan karakter pantai tersebut.

\section{- Amenitas (Amenities)}

Amenitas atau fasilitas akomodasi bagi wisatawan perlu dikembangkan berbagai tipe sarana akomodasi. Bentuk dan tipe sarana akomodasi dapat berupa hotel bintang, hotel melati, dan pondok wisata. Pengembangan yang dilakukan disesuaikan dengan lingkungan setempat. Pantai yang dikembangkan dilengkapi dengan berbagai sarana akomodasi dengan memperhitungkan radius jangkauan dan permintaan pasar. Pengembangan akomodasi ini tidak boleh menyalahi ketentuan peraturan tentang kawasan lindung sempadan pantai.

\section{- Aksesibilitas (Accessibility)}

Pengembangan aksesibilitas dimulai dari pemeliharaan bagi jalan yang telah dibangun dan telah menjangkau ke objek yang sudah ada. Sementara itu, pengembangan aksesibilitas pantai yang akan dikembangkan perlu dilakukan pembangunan jalan dengan intensitas dan keterjangkauan yang tidak merusak ekosistem pantai dan lingkungan sesuai dengan peraturan tentang kawasan lindung sempadan pantai. Bus pariwisata perlu ditambah jumlahnya untuk melayani trayek ke seluruh atraksi pantai. Pelabuhan Perikanan Nusantara (PPN) yang berlokasi di pantai selatan Lombok Tengah diharapkan mampu memberikan kontribusi terhadap peningkatan pendapatan asli daerah 
dan perekonomian masyarakat, serta dari sektor pariwisata diharapkan menjadi pintu masuk wisatawan.

- $\quad$ Fasilitas Pendukung (Ancillary Services)

Fasilitas pendukung yang dapat digunakan oleh wisatawan saat berkunjung ke destinasi pariwisata di Kawasan Ekonomi Khusus Mandalika antara lain: bank, telekomunikasi, kantor pos, serta puskesmas dan puskesmas pembantu. Bank dan kantor pos hanya terdapat di ibukota kecamatan, serta jaringan telekomunikasi sudah ada namun sinyalnya masih kurang baik terutama untuk wilayah Desa Prabu, Selong Belanak, Montong Sapah, Batu Jangkih, dan Montong Ajan. Sementara Puskesmas dan puskesmas pembantu sudah tersedia di kota kecamatan dan desa, namun tenaga dokter, perawat dan tenaga medisnya yang perlu ditambah.

\section{- $\quad$ Kelembagaan (Institutions)}

Institusi, manajemen dan SDM pelayanan pariwisata di wilayah pantai bagian barat telah terbentuk. Tetapi bagi wilayah bagian timur, institusi, manajemen dan SDM pelayanan pariwisata belum memadai. Kualitas SDM yang ada di Kawasan Ekonomi Khusus Mandalika belum dapat melayani kegiatan yang terkait dengan pariwisata secara profesional. Kualitas SDM yang terlibat yang berada dalam institusi pemerintah dan swasta, manajemen dan pelayanan pariwisata perlu dikembangkan agar lebih profesional. Khusus pemandu wisata perlu ditingkatkan pengetahuan dan kemampuannya terhadap potensi wisata yang ada. Untuk ini perlu dilakukan pelatihan yang dilaksanakan oleh swasta dan pemerintah dengan melibatkan lembaga pendidikan untuk mempersiapkan tenaga pemandu yang profesional. Lembaga yang selama ini berusaha di bidang pariwisata dilakukan oleh pengusaha tertentu dari golongan menengah ke atas.

Upaya yang perlu dilakukan adalah meningkatkan minat masyarakat golongan menengah ke bawah untuk ikut membentuk lembaga yang berusaha dan bergerak di bidang pariwisata. Lembaga koperasi, koperasi unit desa atau lembaga masyarakat desa dapat diberdayakan untuk bergerak di bidang pariwisata. Dalam pengembangan kepariwisataan pantai bagian timur pembentukan lembaga birokrasi kepariwisataan perlu segera dibentuk. Selain itu, promosi dalam pengembangan pemasaran diarahkan kepada wisatawan nusantara. Pengembangan promosi dan pemasaran wisatawan minat khusus dilakukan dengan penyempurnaan cara yang tradisional ke cara yang lebih maju dengan perkembangan teknologi komunikasi dan informasi. Kegiatan terpadu dalam promosi dan pemasaran pariwisata akan dapat memberi hasil guna yang lebih baik dengan biaya yang lebih efisien.

2.2 Peraturan Daerah Provinsi Nusa Tenggara Barat No. 7 Tahun 2013 tentang Rencana Induk Pembangunan Kepariwisataan Daerah Tahun 2013-2028

Dalam pembangunan destinasi pariwisata daerah di Provinsi Nusa Tenggara Barat, dilakukan melalui konsep perwilayahan pembangunan destinasi pariwisata yang meliputi Destinasi Pariwisata Daerah (DPD) dan Kawasan Strategis Pariwisata Daerah (KSPD). DPD sendiri dibentuk dengan pembangunan daya tarik wisata, pembangunan aksebilitas pariwisata, pembangunan prasarana umum, fasilitas umum dan fasilitas pariwisata, pemberdayaan masyarakat melalui kepariwisataan, dan pembangunan investasi di bidang pariwisata.

Provinsi Nusa Tenggara Barat terbagi atas 2 (dua) DPD, yaitu DPD Pulau Lombok dan DPD Pulau Sumbawa dengan menetapkan beberapa kawasan yang ada ke dalam kawasan strategis dari sektor pariwisata berupa penetapan sebagai KSPD. Adapun DPD Pulau Lombok itu sendiri terdiri atas 4 (empat) KSPD, yaitu:

a. KSPD Mataram dan sekitarnya meliputi kawasan wisata Kota Mataram, Islamic Center, Loang Baloq, Taman Mayura, Sekarbela, Taman Narmada, Suranadi dan Lingsar sebagai kawasan wisata budaya, religi, kuliner, belanja dan MICE;

b. KSPD Senggigi-Tiga Gili dan sekitarnya meliputi kawasan wisata Batulayar, Batu Bolong, Senggigi, Tiga Gili, Sindang Gila, Senaru, Dusun Tradisional Segenter sebagai kawasan wisata pantai, bawah laut, olah raga berbasis bahari, budaya, religi dan kuliner;

c. KSPD Kuta Mandalika dan sekitarnya meliputi kawasan wisata Gili Gede, Gili Nanggu, BangkoBangko, Selong Blanak, Sade, Kute, Gili Indah sebagai kawasan wisata pantai, bawah laut, olah raga berbasis bahari, dan budaya; dan

d. KSPD Rasimas-Sembalun dan sekitarnya meliputi kawasan wisata Benang Stokel, Gili Sulat, Sembalun, Gunung Rinjani, Otak Kokoq sebagai kawasan wisata agro, pegunungan dan kuliner.

3. Peran Pemerintah dalam Pengembangan Kawasan Ekonomi Khusus Mandalika Provinsi Nusa Tenggara Barat

\begin{tabular}{|c|c|}
\hline Sumber & Normatif \\
\hline $\begin{array}{lr}\text { Peraturan } & \\
\text { Pemerintah } & \text { Nomor } \\
52 \text { Tahun } & 2014 \\
\text { tentang } & \text { Kawasan } \\
\text { Ekonomi } & \text { Khusus } \\
\text { Mandalika } & \end{array}$ & $\begin{array}{l}\text { Pengaturan aspek spasial } \\
\text { berupa lokasi } \\
\text { Ekonomi Khususan Mandalika } \\
\text { yang berada di kecamatan } \\
\text { Pujut }\end{array}$ \\
\hline $\begin{array}{lr}\text { Peraturan } & \text { Menteri } \\
\text { Agraria } & \text { Dan Tata } \\
\text { Ruang/ } & \text { Kepala } \\
\text { Badan } & \text { Pertanahan } \\
\text { Nasional } & \text { Republik } \\
\text { Indonesia Nomor } 24 \\
\text { Tahun } 2016 \text { tentang } \\
\text { Standar Pelayanan } \\
\text { dan } & \text { Pengaturan } \\
\text { Agraria, Tata Ruang } \\
\text { dan Pertanahan di } \\
\text { Kawasan Ekonomi } \\
\text { Khusus }\end{array}$ & $\begin{array}{l}\text { Pengaturan kewenangan } \\
\text { pemerintah pusat melalui } \\
\text { menteri ATR dalam urusan } \\
\text { Hak Guna Bangunan dan Hak } \\
\text { Pakai di Kawasan Ekonomi } \\
\text { Khusus Mandalika }\end{array}$ \\
\hline $\begin{array}{lr}\text { Peraturan } & \text { Daerah } \\
\text { Nomor } 3 & \text { Tahun } \\
2010 & \text { tentang } \\
\text { Rencana Tata Ruang } \\
\text { Wilayah } & \text { Provinsi } \\
\text { Nusa Tenggara Barat }\end{array}$ & $\begin{array}{lr}\text { Pengaturan } & \text { mengenai } \\
\text { penetapan struktur ruang } \\
\text { yang berkaitan dengan } \\
\text { pengembangan Kawasan } \\
\text { Ekonomi Khusus Mandalika } \\
\text { dan arah pengembangannya }\end{array}$ \\
\hline $\begin{array}{lr}\text { Peraturan } & \text { Daerah } \\
\text { Nomor 7 Tahun } 2011 \\
\text { tentang } & \text { RTRW } \\
\text { Kabupaten } & \text { Lombok } \\
\text { Tengah } & \end{array}$ & $\begin{array}{l}\text { Pengaturan aspek spasial } \\
\text { berupa batas-batas Kawasan } \\
\text { Ekonomi Khusus Mandalika }\end{array}$ \\
\hline
\end{tabular}




\begin{tabular}{|c|c|}
\hline Sumber & Normatif \\
\hline & $\begin{array}{lr}\text { Pengaturan } & \text { mengenai } \\
\text { pengembangan } & \text { struktur } \\
\text { ruang yang diturunkan dari } \\
\text { RTRW provinsi } & \text { dalam } \\
\text { kaitannya } & \text { dengan } \\
\text { pengembangan } & \text { Kawasan } \\
\text { Ekonomi Khusus Mandalika } \\
\text { dan pengaturan tata ruang } \\
\text { lokasi pembangunan sarana } \\
\text { dan prasarana yang } \\
\text { menunjang } & \text { kegiatan } \\
\text { perekonomian di Kawasan } \\
\text { Ekonomi Khsusu Mandalika }\end{array}$ \\
\hline $\begin{array}{ll}\text { Rencana } & \text { Induk } \\
\text { Pengembangan } \\
\text { Pariwisata Daerah } \\
\text { Kabupaten Lombok } \\
\text { Tengah }\end{array}$ & $\begin{array}{lrr}\text { Pengaturan } & \text { aspek } & \text { spasial } \\
\text { mengenai } & \text { pembagian } \\
\text { kawasan } & \text { pengembangan } \\
\text { Kawasan } & \text { Ekonomi } & \text { Khusus } \\
\text { Mandalika } & & \\
\end{array}$ \\
\hline & $\begin{array}{l}\text { Pengaturan aspek pariwisata } \\
\text { berupa pengembangan } \\
\text { komponen pariwisata seperti } \\
\text { attractions, amenities, } \\
\text { accessibilities, anciliary, dan } \\
\text { institution di Kawasan } \\
\text { Ekonomi Khusus Mandalika }\end{array}$ \\
\hline $\begin{array}{lr}\text { Peraturan } & \text { Daerah } \\
\text { Provinsi Nusa } & \text { Nenggara Barat No. } 7 \\
\text { Tengan 2013 tentang } \\
\text { Tahun } \\
\text { Rencana Induk } \\
\text { Pembangunan } \\
\text { Kepariwisataan } \\
\text { Daerah Tahun 2013- } \\
\text { 2028 }\end{array}$ & 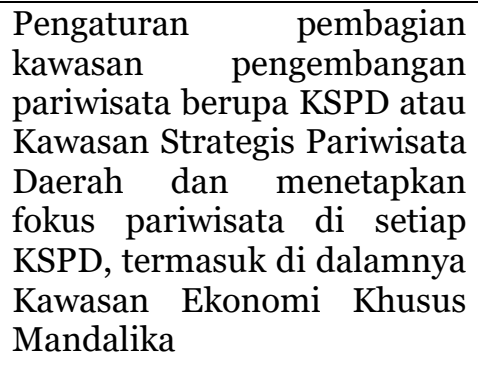 \\
\hline
\end{tabular}

\section{SIMPULAN DAN SARAN}

\section{Kesimpulan}

Kesimpulan dari penelitian Peran Pemerintah Dalam Pengembangan Kawasan Ekonomi Khusus Mandalika Kabupaten Lombok Tengah Provinsi Nusa Tenggara Barat adalah pemerintah kabupaten Lombok Tengah sebagai aktor pengembangan Kawasan Ekonomi Khusus Mandalika yang berperan paling besar dibandingkan level pemerintah yang lainnya.

Hal ini bisa terlihat pada institutional setting aspek spasial. Rencana Induk Pengembangan Pariwisata Daerah Kabupaten Lombok Tengah memberikan penjelasan secara detail mengenai pembagian kawasan pariwisata menjadi kawasan pengembangan utara, kawasan pengembangan tengah, dan kawasan pengembangan selatan. Sedangkan peraturan lain yang menyangkut Kawasan Ekonomi Khusus Mandalika hanya membahas mengenai delineasi dan batas-batasnya saja.

Aspek pariwisata dalam institutional setting di Kawasan Ekonomi Khusus Mandalika juga berfokus pada level kabupaten. Rencana Induk Pengembangan Pariwisata Daerah Kabupaten Lombok Tengah menjelaskan secara detail pengembangan pariwisata yang ada di Kawasan Ekonomi Khusus Mandalika. Aspek pariwisata dalam institutional setting di Kawasan Ekonomi Khusus Mandalika diperkuat dengan adanya 5.2.2 Peraturan Daerah Provinsi Nusa Tenggara Barat No. 7 Tahun 2013 tentang Rencana Induk Pembangunan Kepariwisataan Daerah Tahun 2013-2028 yang membahas pengembangan kawasan dengan pembagian Kawasan Strategis Pariwisata Daerah (KSPD) yang ada di Kawasan Ekonomi Khusus Mandalika.

\section{Saran}

Penelitian ini tentu masih banyak kekurangan, sehingga masih perlu banyak masukan untuk penelitian yang lebih baik. Saran untuk penelitian selanjutnya adalah untuk mengkaji lebih dalam komponen komponen pariwisata beserta perkembangannya dari tahun ke tahun (time series). Sedangkan saran untuk institusi terkait pengembangan pariwisata bisa lebih mendetailkan pengembangan atraksi, amenitas, dan aksesibilitas di Kawasan Ekonomi Khusus Mandalika, terutama berkaitan dengan pengembangan pariwisata yang berkelanjutan.

\section{DAFTAR RUJUKAN}

[1] Çakmak, E., Lie, R., Mccabe, S., Reframing informal tourism entrepreneurial practices: Capital and field relations structuring the informal tourism economy of Chiang Mai. Ann. Tour. Res. 72, 37-47. https://doi.org/10.1016/j.annals.2018.06.003, 2018.

[2] Distanont, A., Khongmalai, O., Rassameethes, R., Distanont, S. Collaborative triangle for effective community water resource management in Thailand. Kasetsart J. Soc. Sci. 39, 374-380. https://doi.org/10.1016/j.kjss.2017.07.015, 2018

[3] Hakim, L. Dasar-Dasar Ekowisata. Bayumedia, Malang. 2004.

[4] Hossain, S., Scholz, W., Baumgart, S. Translation of urban planning models: Planning principles, procedural elements and institutional settings. Habitat Int. 48, 140148. https://doi.org/10.1016/j.habitatint.2015.03.006, 2015 .

[5] Kotler, P., Haider, D.H., Rein, I. Marketing Places: Attracting Investment, Industry, and Tourism to Cities, States, and Nations. The Free Press A Division of Maximilian, Inc., New York, 1993.

[6] Law, A., DeLacy, T., McGrath, G.M. A green economy indicator framework for tourism destinations. J. Sustain. Tour. 25, 1434-1455. https://doi.org/10.1080/09669582.2017.1284857, 2017.

[7] Manrai, L.A., Manrai, A.K., Friedeborn, S. Environmental determinants of destination competitiveness and its Tourism Attractions-Basics-Context, A-B-C, indicators. J. Econ. Financ. Adm. Sci. https://doi.org/10.1108/jefas-012018-0010, 2018.

[8] Taguchi, N. Description and explanation of pragmatic development: Quantitative, qualitative, and mixed methods research. System 75, 23-32, 2018.

[9] Yunus, H.S. Metodologi Penelitian Wilayah Kontemporer. Pustaka Pelajar, Yogyakarta, 2010. 